\title{
Rural Level Impact of China Free-aid Water Project in Nigeria
}

\author{
Rosemary I. Eneji ${ }^{1} \&$ Xiaoyun $\mathrm{Li}^{1, *}$ \\ ${ }^{1}$ Department of Sociology, University of Calabar, Nigeria \\ *College of Humanities and Development, China Agricultural University, Beijing, China. \\ E-mail: rieneji2@yahoo.com
}

Received: October 31, 2018 Accepted: November 28, 2018 Published: January 20, 2019

doi:10.5296/jsr.v10i1.14291 URL: https://doi.org/10.5296/jsr.v10i1.14291

\begin{abstract}
The objective of this study was to determine the socio-economic impact of Chinese involvement in the provision of potable water at the community level in Nigeria. We specifically determined how the water projects have contributed to health, education and personal income. The study was carried out in Toge/Gasa rural village located at the outskirts of Nigeria's federal capital territory (FCT), Abuja. A combination of informal interviews as well as structured and semi-structured questionnaires was used. Before the water project, 70\% of the beneficiaries relied on personal wells, $10 \%$ on rivers/stream and $20 \%$ on commercial boreholes. Only $12 \%$ of respondents agreed that the volume of water for domestic use before the borehole project was sufficient but $68 \%$ of people had sufficient water after the borehole project. Further, $78 \%$ of respondents considered the quality of water from project boreholes to be much better than what they had before. In contrast, some $75 \%$ of non-beneficiaries of the borehole water project still lacked enough water for daily use.
\end{abstract}

Keywords: Water aid, China, Nigeria, Boreholes 


\section{Introduction}

Diplomatic relations between Nigeria and China started since 1971 and have strengthened significantly in recent years. Visits have been exchanged between presidents of both countries, yielding lots of benefits for both nations. During (Nigerian) President Obasanjo's 2001 visit, both leaders signed agreements on trade, investment promotion and protection, supporting agreements on sincere friendship, mutual trust, mutual economic benefit and common development, and enhanced consultation and mutual support. In April 2002, the two governments signed an agreement to avoid double taxation and prevent fiscal evasion with respect to taxes on income. Both nations agreed to establish a strategic partnership featuring mutual political trust, mutual economic benefit and mutual support in international affairs in 2005.

After almost sixty years of some investment in water supply in Nigeria, as many as $43 \%$ of the population still lack access to safe water. The situation in the rural areas is particularly bad compared to the urban areas (NISER) (1982). Water resources management and utilization is crucial to the Nigeria's efforts to reduce poverty, grow the economy, ensure food security and maintain the ecological balance (Olokesusi, 2004). Due to poor access to ample water supply, sanitation is low in Nigeria. Consequently, there is a high incidence of communicable diseases that often impair the vitality and economic productivity of the people (WHO, 1970; Postel, 1985; Chandler, 1985).

Human welfare and economic development generally depend on the use of water. If properly managed, water can be an instrument for economic survival and growth. It can also be an instrument for poverty alleviation and prosperity to all (UN-WATER/AFRICA, 2004). However, when it is inadequate in either quantity or quality, water can be a limiting factor in poverty alleviation and economic recovery, resulting in poor health and low productivity, food insecurity and constrained economic development. Figure 1 depicts the multi-level impact of water supply on other sectors as well as the larger paradigm of poverty and productivity. By directly impacting key indicators in the health, education, agriculture/food security, and environment sectors, water supply has a profound impact on quality of life indicators and is a major determinant of productivity and poverty levels. This is relevant and accurate in countries like Nigeria where sectors such as agriculture, health and education are vulnerable and thus the need for water supply to be the centerpiece of any lending portfolio is stronger.

Nigeria and China signed a contract agreement for the construction of water schemes in some Nigerian states, including the Federal Capital Territory (FCT) at a cost of 40.27 million Chinese Yuan or N695 million in 2005. The water schemes were equipped with motorized boreholes to cover 10 beneficiary states of Ekiti, Ogun, Oyo, Anambra, Enugu, Imo, Delta, Akwa Ibom, Rivers, Sokoto, Kaduna, Kano, Adamawa, Bornu, Taraba, Kogi, Benue, Niger and FCT. Yongqiu Beijing G \& M Engineering Construction Ltd was commissioned by the Chinese Government to undertake the China-assisted borehole drilling and water supply project in Nigeria. The Chinese water control personnel and their Nigerian counterparts constructed four projects, namely 1) water-saving project across all program sites, 2) well 


\section{Macrothink}

Journal of Sociological Research

ISSN 1948-5468

2019, Vol. 10, No. 1

development project for water supply and irrigation, 3) comprehensive water and soil conservation control project in hilly areas with serious soil erosion, and 4) dam construction projects throughout the country. Also developed or rehabilitated within the four projects were 20 earth dams, 92 boreholes, 2 wells and 5 rain harvesting tanks. In addition, 20 demonstration areas for water saving irrigation were developed.

The objectives of the Study was to determine how the water projects have contributed to education, health, personal income and water availability in the project area of Toge/Gasa, FCT, Abuja, Nigeria.

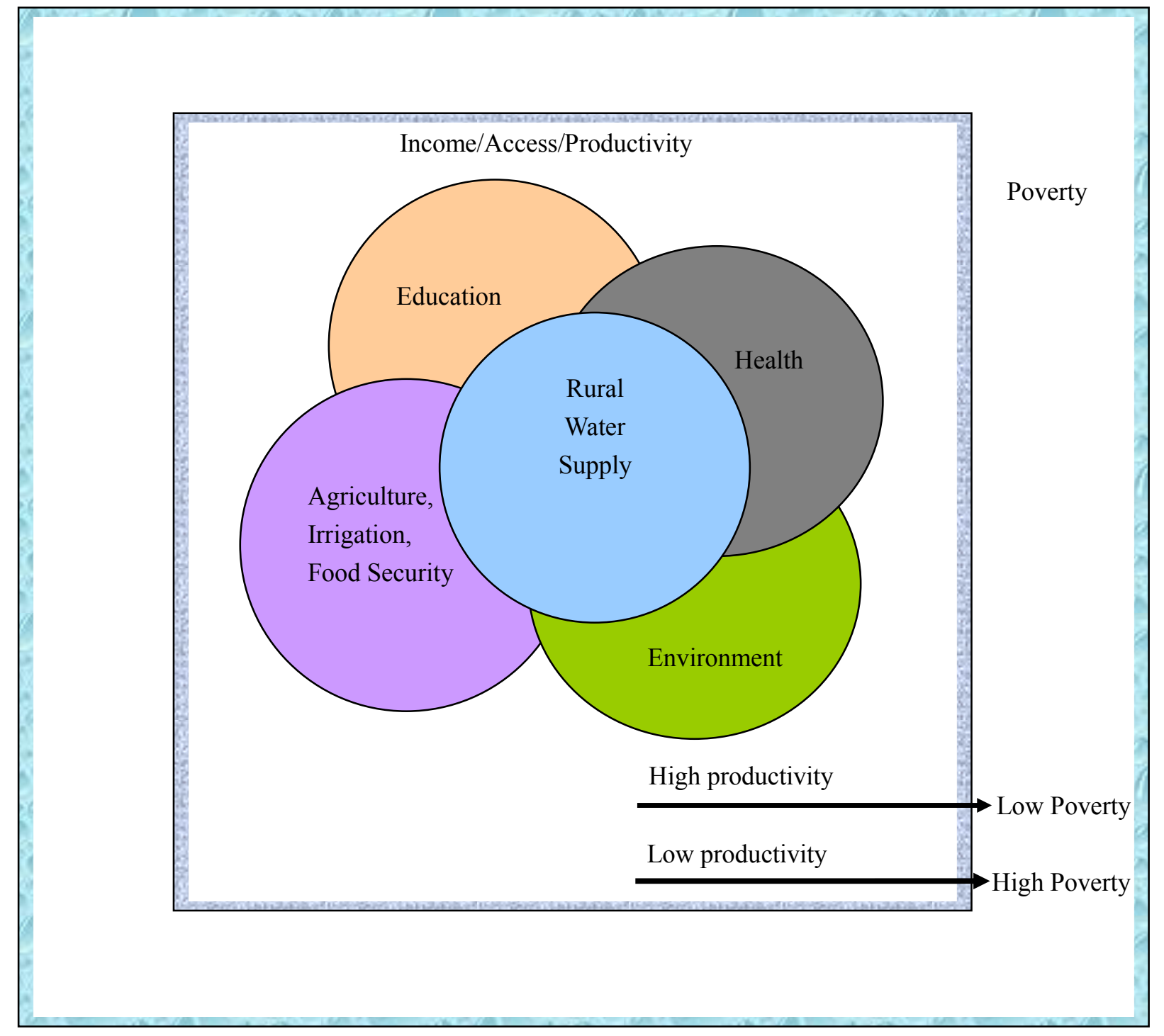

Figure 1. Multi-level Impact of Water Supply on Other Sectors and the Larger Paradigm of Poverty and Productivity 


\section{Methodology}

\subsection{The Study Area}

The study was carried out in two rural villages located at the outskirts of Nigeria's federal capital territory (FCT), Abuja, namely Gasa/Toge where 5 boreholes and an irrigation intervention from the Water Project by Chinese experts were established.

\subsection{Data Collection}

The study adopted a combination of qualitative and quantitative methodology, including informal interviews with some citizens as well as structured and semi-structured questionnaire surveys. Relevant programme documents of projects were collected and reviewed. In addition, discussions were held with some senior government officials in the Ministry of Water Resources. Fifty questionnaires each were administered to randomly selected beneficiaries and non-beneficiaries.

\subsection{Data Analysis}

The questionnaires had several closed ended questions with appropriate rating scales hence, SPSS software was used in the analysis. Simple frequencies and percentages generated from the analysis are summarised in tables and figures.

\section{Results}

\subsection{Beneficiaries}

The respondents for the water supply project were dominated by females who made up $82 \%$ compared with only $18 \%$ for males (Figure 2). Those aged $<20$ years constituted $20 \%$, those aged 21-30 years were 34\%, those aged 31-40 years were $24 \%$, those aged $41-50$ years made up 18\% while those aged 51-60 years constituted only $4 \%$. Eighty percent of the respondents were married, $16 \%$ were single and $4 \%$ were divorced. In terms of religion, $54 \%$ were Moslems while $46 \%$ were Christians. Twenty two percent of the respondents had no formal education, $48 \%$ had primary education, $30 \%$ had secondary education.

The opinions of beneficiaries of the borehole project are shown in Table 1. Before the borehole project, $70 \%$ of respondents relied on personal boreholes, $10 \%$ on rivers/stream and $20 \%$ on commercial wells. Only $12 \%$ of respondents agreed that the amount of water for domestic use before the borehole project was sufficient but $68 \%$ of the beneficiaries had sufficient water after the borehole project; and $78 \%$ of respondents noted that the quality of water from project borehole was much better than what they had before. Although, 10-20\% of household income was spent on water before the borehole project, respondents were benefiting freely from the boreholes. Forty percent of the respondents used the money saved from not buying water for their business, $18 \%$ used it to pay children's school fees while $42 \%$ used it for food.

Some $54 \%$ of beneficiaries used the borehole water to grow their businesses while $42 \%$ 


\section{Macrothink Institute ${ }^{T M}$}

reported an increase in household income due to the boreholes. Fifty six percent of respondents covered shorter distances to fetch water from the project boreholes compared with before while 58\% reported that queues for the boreholes were understandably longer, possibly because it was free and the water quality was better. The time saved from searching for water was very helpful to $68 \%$ of respondents and moderately helpful to $28 \%$ of them. Also, $66 \%$ of respondents were of the opinion that the time saved was helpful to girl child education. Overall, the perception of the Chinese by the local people was positive (76\%) and local people $(84 \%)$ do not consider the borehole project to have negative environmental effects. Majority (82\%) of the respondents held that the aid activities of the Chinese would help the local government improve their lives.
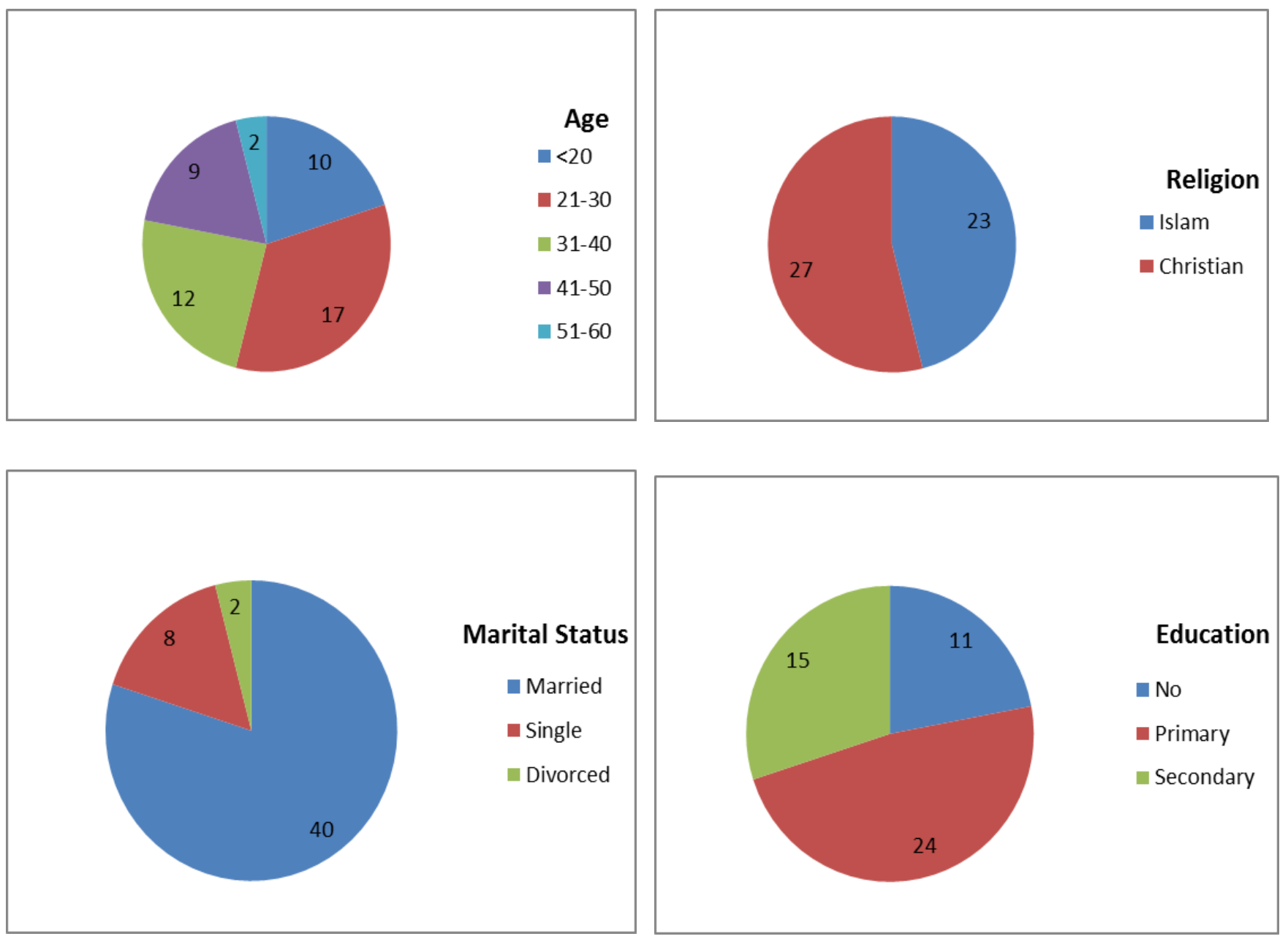

Figure 2. Background Information on Respondents (beneficiaries) for the Borehole Project in Gasa/Togoe village, Abuja, Nigeria 
Table 1. Opinions of Respondents (beneficiaries) for the Borehole Project in Gasa/Toge, FCT, Nigeria

\begin{tabular}{|c|c|c|c|c|}
\hline $\mathrm{S} / \mathrm{N}$ & & & & \\
\hline 1. & Benefiting from the Chinese borehole & $\begin{array}{l}\text { Yes: } \\
31(62 \%)\end{array}$ & $\begin{array}{l}\text { No: } \\
19(38 \%)\end{array}$ & \\
\hline 2. & Source of water before Chinese borehole & $\begin{array}{l}\text { Personal } \\
\text { Well: } \\
35(70 \%)\end{array}$ & $\begin{array}{l}\text { River/stream: } \\
5(10 \%)\end{array}$ & $\begin{array}{l}\text { Commercial } \\
\text { wells: } \\
10(20 \%)\end{array}$ \\
\hline 3. & $\begin{array}{l}\text { Amount of water for house use before } \\
\text { borehole project }\end{array}$ & $\begin{array}{l}\text { Sufficient: } \\
6(12 \%)\end{array}$ & $\begin{array}{l}\text { Not sufficient: } \\
33(66 \%)\end{array}$ & $\begin{array}{l}\text { Somehow: } \\
11(22 \%)\end{array}$ \\
\hline 4. & $\begin{array}{l}\text { Number of people benefiting daily from } \\
\text { borehole }\end{array}$ & $\begin{array}{l}\text { 20-50: } \\
29(58)\end{array}$ & $\begin{array}{l}>\mathbf{5 0}: \\
21(42 \%)\end{array}$ & \\
\hline 5. & $\begin{array}{l}\text { Number of people with sufficient water } \\
\text { for daily use after project }\end{array}$ & $\begin{array}{l}\text { Yes: } \\
34(68 \%)\end{array}$ & $\begin{array}{l}\text { Somehow: } \\
11(22 \%)\end{array}$ & $\begin{array}{l}\text { No: } \\
5(10 \%)\end{array}$ \\
\hline 6. & $\begin{array}{l}\text { Quality of borehole water vs well/river } \\
\text { water }\end{array}$ & $\begin{array}{l}\text { The same: } \\
13(26 \%)\end{array}$ & $\begin{array}{l}\text { Better: } \\
37(74 \%)\end{array}$ & \\
\hline 7. & $\begin{array}{l}\text { Number of people who bought water } \\
\text { before the borehole project }\end{array}$ & $\begin{array}{l}\text { Yes: } \\
43(86 \%)\end{array}$ & $\begin{array}{l}\text { No: } \\
7(14 \%)\end{array}$ & \\
\hline 8. & $\begin{array}{l}\text { Percent of income spent on water before } \\
\text { project }\end{array}$ & $\begin{array}{l}\text { 10\%: } \\
27(54 \%)\end{array}$ & $\begin{array}{l}\text { 20\%: } \\
15(30 \%)\end{array}$ & $\begin{array}{l}\text { No: } \\
8(16 \%)\end{array}$ \\
\hline 9. & Payment to use Chinese borehole & Yes: $0(0 \%)$ & No: $50(100 \%)$ & \\
\hline 10. & $\begin{array}{l}\text { Use of money saved from not paying for } \\
\text { water from Chinese borehole }\end{array}$ & $\begin{array}{l}\text { Business: } \\
20(40 \%)\end{array}$ & $\begin{array}{l}\text { School fees: } \\
9(18 \%)\end{array}$ & $\begin{array}{l}\text { Food: } \\
21(42 \%)\end{array}$ \\
\hline 11. & Use of borehole water to grow business & $\begin{array}{l}\text { Yes: } \\
27(54 \%)\end{array}$ & $\begin{array}{l}\text { No: } \\
23(46 \%)\end{array}$ & \\
\hline 12. & $\begin{array}{l}\text { Increase in household income due to } \\
\text { borehole }\end{array}$ & $\begin{array}{l}\text { Yes: } \\
21(42 \%)\end{array}$ & $\begin{array}{l}\text { No: } \\
29(58 \%)\end{array}$ & \\
\hline 13. & $\begin{array}{l}\text { Distance to fetching water from Chinese } \\
\text { borehole compared with before }\end{array}$ & $\begin{array}{l}\text { The same: } \\
12(24 \%)\end{array}$ & $\begin{array}{l}\text { Shorter: } \\
28(56 \%)\end{array}$ & $\begin{array}{l}\text { Longer: } \\
10(20 \%)\end{array}$ \\
\hline 14. & $\begin{array}{l}\text { The queue to fetch water from Chinese } \\
\text { borehole compared with that for } \\
\text { commercial borehole }\end{array}$ & $\begin{array}{l}\text { The same: } \\
17(34 \%)\end{array}$ & $\begin{array}{l}\text { Less: } \\
4(8 \%)\end{array}$ & $\begin{array}{l}\text { Longer: } \\
29(58 \%)\end{array}$ \\
\hline 15. & $\begin{array}{l}\text { Effect of time saved for fetching water } \\
\text { on other activities }\end{array}$ & $\begin{array}{l}\text { Very helpful: } \\
32(68 \%)\end{array}$ & $\begin{array}{l}\text { Moderately } \\
\text { helpful: } \\
14(28 \%)\end{array}$ & $\begin{array}{l}\text { Not helpful: } \\
4(8 \%)\end{array}$ \\
\hline 16. & $\begin{array}{l}\text { Can time saved help girls to go to } \\
\text { school? }\end{array}$ & $\begin{array}{l}\text { Yes: } \\
33(66 \%)\end{array}$ & $\begin{array}{l}\text { No: } \\
6(12 \%)\end{array}$ & $\begin{array}{l}\text { Don't know: } \\
11(22 \%)\end{array}$ \\
\hline 17. & Perception of Chinese water aid & $\begin{array}{l}\text { Positive: } \\
38(76 \%)\end{array}$ & $\begin{array}{l}\text { Indifferent: } \\
12(24 \%)\end{array}$ & \\
\hline 18. & $\begin{array}{l}\text { Environmental effect of Chinese } \\
\text { borehole }\end{array}$ & $\begin{array}{l}\text { No effect: } \\
42(84 \%)\end{array}$ & $\begin{array}{l}\text { Don't know: } \\
8(16 \%)\end{array}$ & \\
\hline 19. & $\begin{array}{l}\text { Opinion of Chinese Government helping } \\
\text { Nigerian Government to help the poor }\end{array}$ & $\begin{array}{l}\text { Yes: } \\
41(82 \%)\end{array}$ & $\begin{array}{l}\text { Not really: } \\
9(18 \%)\end{array}$ & \\
\hline
\end{tabular}




\subsection{Non-beneficiaries}

A summary of background, responses and opinions of non-beneficiaries (those living rather too far from the new water sources) of the water project is shown in Table 2. About half of them were aged 31-40 years, comprising 28 males and 22 females. Most (84\%) of them were married and $56 \%$ of them had secondary education. All the non-beneficiaries had no Chinese supported boreholes in their domain; hence they sourced their water from streams $(50 \%)$, hand-dug wells (36\%) and commercial boreholes (14\%). About $76 \%$ of non-beneficiaries had not enough water for daily needs. As a result, $40-45 \%$ of them spend between $5-20 \%$ of their income on water. About $90 \%$ of respondents wished to have Chinese boreholes in their domains.

Table 2. Background, Responses and Opinions of Non-beneficiaries of the Borehole Project

\begin{tabular}{|c|c|c|c|c|c|}
\hline \multicolumn{6}{|l|}{$\mathrm{S} / \mathrm{N}$} \\
\hline 1. & Sex & $\begin{array}{l}\text { Male: } \\
28(55 \%)\end{array}$ & $\begin{array}{l}\text { Female: } \\
22(45 \%)\end{array}$ & & \\
\hline 2. & Age & $<20: 3(5 \%)$ & $20-31: 10(20 \%)$ & $31-40: 25(50 \%)$ & $51-60: 12(25 \%)$ \\
\hline 3. & Marital stats & $\begin{array}{l}\text { Married: } \\
42(84 \%)\end{array}$ & $\begin{array}{l}\text { Single: } \\
8(16 \%)\end{array}$ & & \\
\hline 4. & Religion & $\begin{array}{l}\text { Traditional: } \\
10(20 \%)\end{array}$ & $\begin{array}{l}\text { Christianity: } \\
40(80 \%)\end{array}$ & & \\
\hline 5. & Education: & $\begin{array}{l}\text { No: } \\
10(20 \%)\end{array}$ & $\begin{array}{l}\text { Primary: } \\
12(24 \%)\end{array}$ & $\begin{array}{l}\text { Secondary: } \\
28(56 \%)\end{array}$ & \\
\hline 6. & $\begin{array}{l}\text { Presence of Chinese } \\
\text { boreholes }\end{array}$ & $\begin{array}{l}\text { No: } \\
50(100 \%)\end{array}$ & & & \\
\hline 7. & Sources of water & $\begin{array}{l}\text { Stream: } \\
25(50 \%)\end{array}$ & $\begin{array}{l}\text { Well: } \\
18(36 \%)\end{array}$ & $\begin{array}{l}\text { Buying: } \\
7(14 \%)\end{array}$ & \\
\hline 8. & $\begin{array}{l}\text { Sufficiency of water } \\
\text { for daily needs }\end{array}$ & $\begin{array}{l}\text { Yes: } \\
12(24 \%)\end{array}$ & $\begin{array}{l}\text { No: } \\
38(76 \%)\end{array}$ & & \\
\hline 9. & $\begin{array}{l}\text { use of water for } \\
\text { business }\end{array}$ & $\begin{array}{l}\text { No: } \\
33(66 \%)\end{array}$ & $\begin{array}{l}\text { Yes: } \\
17(34 \%)\end{array}$ & & \\
\hline 10. & $\begin{array}{l}\text { Percent of income used } \\
\text { for water }\end{array}$ & $\begin{array}{l}5-10 \%: \\
8(40 \%)\end{array}$ & $\begin{array}{l}10-20 \%: \\
9(45 \%)\end{array}$ & $\begin{array}{l}20-30 \%: \\
3(15 \%)\end{array}$ & \\
\hline 11. & $\begin{array}{l}\text { Awareness of Chinese } \\
\text { boreholes }\end{array}$ & $\begin{array}{l}\text { Yes: } \\
28(56 \%)\end{array}$ & $\begin{array}{l}\text { No: } \\
22(44 \%)\end{array}$ & & \\
\hline 12. & $\begin{array}{l}\text { Desire for Chinese } \\
\text { borehole }\end{array}$ & $\begin{array}{l}\text { Yes: } \\
45(90 \%)\end{array}$ & $\begin{array}{l}\text { Don’t know: } \\
5(10 \%)\end{array}$ & & \\
\hline
\end{tabular}

\subsection{Livelihood Change across Project Beneficiaries}

For household water supplies $12 \%$ of the beneficiaries had enough water for daily use compared with $68 \%$ after the boreholes were drilled (Figure 3). Therefore, the number that 
bought water after the borehole drilling fell from $86 \%$ to only $47 \%$. Also, $54 \%$ of respondents agreed that the borehole water boosted their businesses than before. As a result of increased personal incomes of beneficiaries, they were able to improve their life style by purchasing more household supplies and even items like mobile phones and motorbikes. Most were able to pay children's school fees promptly and afford their health bills and taxes.

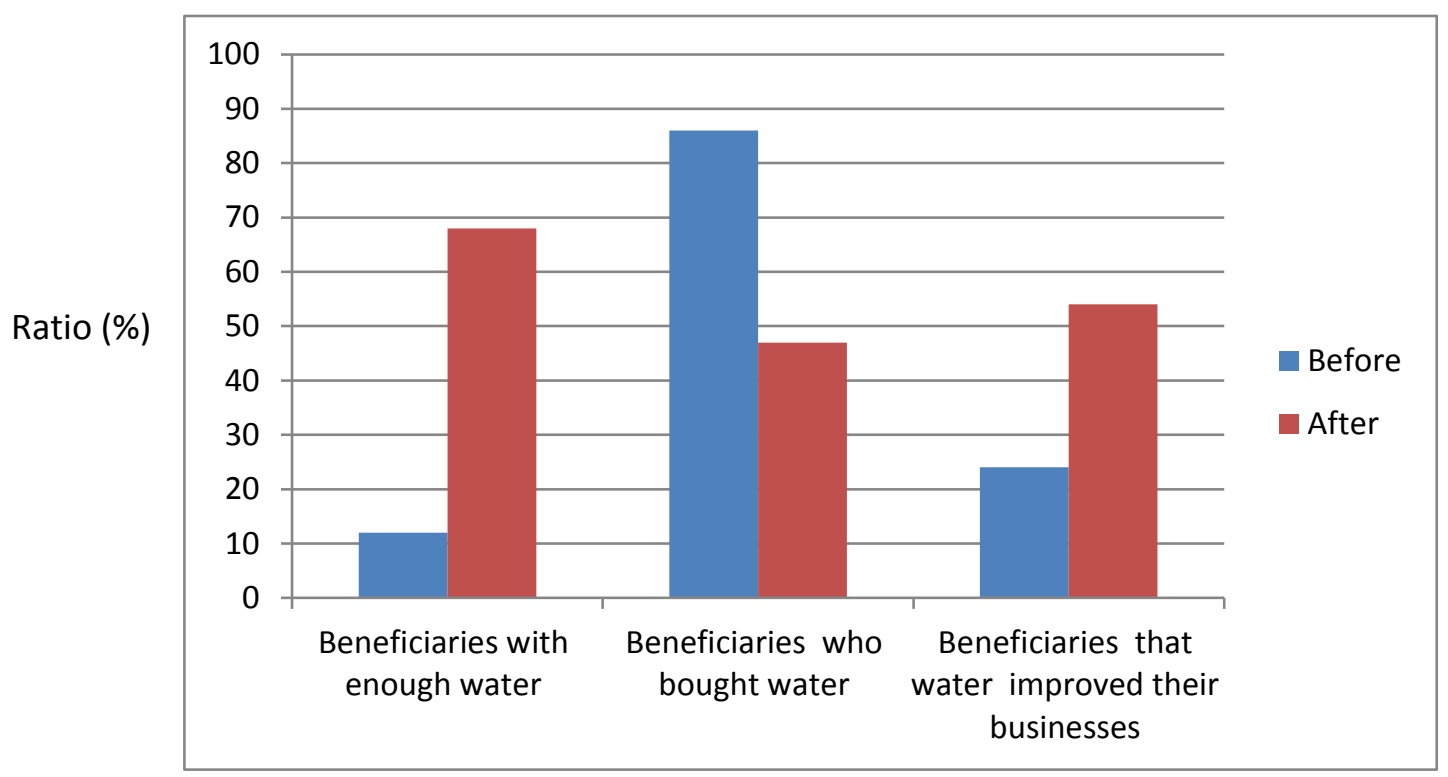

Figure 3. Ratio of Beneficiaries Who Had Enough, Bought or Used Water to Grow Businesses before versus after the Borehole Project

\section{Discussion}

Poor water supply facilities have made access to clean drinking water impossible for majority of Nigerian people. As a result, every year witnesses millions of people suffering from such water-infected diseases as enteritis, diarrhea and cholera and deaths of hundred of thousands of people. Majority of the people fetch water from unclean or even polluted rivers and creeks. Water resources management and utilization is crucial to Nigeria's efforts to reduce poverty, grow the economy, ensure food security and maintain the ecological systems. Groundwater is considered not only feasible but also the most economic source of rural potable water supply. The groundwater has numerous advantages as the main source of rural water supply in Nigeria. Firstly, there are aquifers underlying geographically large areas of the country that can be tapped at shallow depths close to the demand centers in response to the dispersed nature of rural settlements. Some of these aquifers were assessed by Chinese experts and their characteristics were fairly well known. Secondly, water stored in aquifers is naturally protected from evaporation, and well yields are in many cases adequate, offering water security in areas prone to protracted droughts as experienced in the northern parts of the country. Thirdly, with aquifer protection, groundwater has excellent microbiological and chemical quality which require minimal or no treatment. Lastly, the capital cost of 
groundwater development as opposed to conventional treatment of surface waters is relatively modest and the resource lends itself to flexible development capable of being phased with rising demand.

With help from China, many boreholes were drilled in Nigeria's capital, Abuja and 18 states under a free- aid project. The project aimed at providing clean drinkable water to ordinary Nigerians living in remote areas. The opinions of beneficiaries in Gasa/Toge village under the Federal capital territory of Abuja (Table 3) indicated that before the borehole project, $70 \%$ of respondents relied on hand-dug, seasonal wells, $10 \%$ on rivers/stream and $20 \%$ on commercial boreholes. As indicated in our data, $68 \%$ of people had sufficient water after the borehole project; and $78 \%$ of beneficiaries noted that quality of water from project borehole was much better than what they had before. Thus, about, 10-20\% of their meager household income which was spent on water before the borehole project was used to improve people's lives in other areas. Forty percent of the respondents invested the money saved from not buying water in their businesses, $18 \%$ used it to pay children's school fees while $42 \%$ used it for food. Some $54 \%$ of beneficiaries used the borehole water to grow their businesses while $42 \%$ reported an increase in household income due to the borehole. The reduction in time spent hunting water for fifty six percent of beneficiaries meant that they now have time to pursue other economic and social goals in their communities. The time saved from searching for water was very helpful to $68 \%$ of respondents and moderately helpful to $28 \%$ of them. Also, $66 \%$ of respondents were of the opinion that the time saved was helpful to girl child education. For instance, the enrolment of girls in schools was high in villages with boreholes compared to non- boreholes ones. However, queues for the borehole water were understandably longer, possibly because it was free and the water quality was better. Overall, the perception of Chinese by the local people was positive (76\%) and local people (84\%) do not consider the borehole project to have negative environmental effects. Majority (82\%) of the respondents held that the aid activities of the Chinese would help the local government improve their lives.

\section{Summary}

The overall conclusion is that Chinese involvement in Nigeria's water supply is a significant positive contribution to people's welfare at the community level. For an even greater benefit, we recommend that China should make aid effectiveness a high priority and commit to accelerating progress in its implementation by:

a) Promoting the alignment of aid with Nigeria's priorities, systems and procedures and helping to strengthen their capacities.

b) Avoiding duplication of efforts and focusing activities in neglected sectors such as agriculture and water supply in a cost-effective manner, while encouraging collaborative behaviour and

c) Demanding that the culture of maintenance be vigorously pursued to ensure that boreholes developed with Chinese expertise are carefully used over longer periods. 


\section{References}

Conference on Science, Technology' Water and Environment in Africa. Held at ILRI Campus, Addis Ababa, Ethiopia.

NISER. (1982). Oyo State Survey of Resources for Development. NISER, Ibadan, Nigeria.

Olokesusi, F. (2004). A Survey of Indigenous Water Management and Coping Mechanisms in Africa: Implications for knowledge and Technology Policy. Paper Presented at the ATPS/EIIPD.

Postel, S. (1985). Conserving Water: The Untapped Alternative. Worldwatch Institute, Washington, DC.

United Nations Statistics Division (UN-STATS). Various Indicators and years from Multiple Databases. Retrieved from http://unstats.un.org/unsd

World Health Organization. (1970). Strategy of Cholera Control, Proceedings of WHO Seminar on the Organisation of Cholera Control, Manila 6-9 October, (BD/Cholera/71.1, Geneva, 1971).

\section{Copyright Disclaimer}

Copyright for this article is retained by the author(s), with first publication rights granted to the journal.

This is an open-access article distributed under the terms and conditions of the Creative Commons Attribution license (http://creativecommons.org/licenses/by/3.0/). 